\title{
PENGUASAAN HAK ATAS TANAH BAGI BADAN HUKUM ASING DI INDONESIA
}

\author{
Desy Nurkristia Tejawati \\ Fakultas Hukum, Universitas Wijaya Kusuma Surabaya \\ e-mail: desynurkristiatejawati_fh@uwks.ac.id
}

\begin{abstract}
ABSTRAK
Hak atas tanah merupakan suatu hak yang melekat dan tidak dapat dihilangkan begitu saja yang berisikan penguasaan dan pemilikan. Penguasaan hak atas tanah berisi serangkaian wewenang, kewajiban dan/atau larangan bagi pemegang haknya untuk berbuat sesuatu mengenai tanah yang dikuasainya. Kedudukan badan hukum asing di Indonesia dalam hal penguasaan hak atas tanah adalah dengan menjadi subyek pemegang hak pakai dan hak sewa atas tanah. Badan hukum asing dalam hukum Indonesia merupakan badan hukum privat dan publik, sehingga badan hukum asing dengan adanya modal yang dimiliki yaitu modal asing sehingga dapat melakukan investasi di Indonesia. Undang-Undang No. 5 Tahun 1960 tentang Peraturan Dasar Pokok-Pokok Agraria mengatur mengenai pembatasan dan pengecualian dalam hal pemilikan hak atas tanah oleh orang asing dan badan hukum asing. Undang-Undang No. 25 Tahun 2007 tentang Penanaman Modal memberikan kemudahan pada badan hukum asing berkaitan dengan penguasaan hak atas tanah dalam melakukan investasi di Indonesia. Hal yang bertentangan tersebut menimbulkan problematika berkaitan dengan penguasaan hak atas tanah oleh badan hukum asing di Indonesia.
\end{abstract}

Kata Kunci: Hak Atas Tanah; Penguasaan Tanah; Badan Hukum Asing

\begin{abstract}
The right to land is an inherent right and cannot be just eliminated, which contains control and ownership. Mastery of land rights contains a series of powers, obligation, and or prohibitions for rights holders to do something about the land and they control. The position of foreign legal entities in Indonesia in terms of control over land rights is by becoming the subject of holders of use rights and lease rights over land. Foreign legal entities in Indonesian law are private and public legal entities, so that foreign legal entities with their own capital so they can invest in Indonesia. Act Number 5 Year 1960 on Basic Agrarian Principles regulates restrictions and exceptions in terms of ownership of land rights by foreigners and foreign legal entities. Act Number 25 Year 2007 about capital investment provide convenience to foreign legal entities relating to control of land rights in investing in Indonesia. This contradiction creates problems related to the control of land rights by foreign legal entities in Indonesia.
\end{abstract}

Keywords: Land Rights; Land Tenure; Foreign Legal Entity

\section{PENDAHULUAN}

Negara Indonesia sebagai negara yang menegaskan dirinya sebagai "Negara Agraris" menempatkan tanah pada kedudukan yang sangat penting. Begitu pentingnya tanah, sehingga konstitusi memberikan amanat kepada negara untuk melindunginya. ${ }^{1}$ Tanah merupakan suatu sumber daya alam yang penting bagi kelangsungan hidup umat manusia, hubungan antara manusia dengan tanah bukan hanya sekedar tempat untuk hidup melainkan

1 Anna Triningsih dan Zaka Firma Aditya. (2019). "Pembaharuan Penguasaan Hak Atas Tanah Dalam Perspektif Konstitusi”. Rechtsvinding. Vol. 8 No. 3, h. 330. 
lebih daripada itu. Tanah merupakan tempat dimana manusia dapat hidup dan berkembang selain itu tanah juga menjadi sumber bagi segala kepentingan hidup umat manusia. Tanah dapat dinilai sebagai suatu harta yang mempunyai sifat permanen karena tanah memberikan suatu kemantapan untuk dicadangkan bagi kehidupan di masa mendatang. Selain itu tanah merupakan tempat bermukim dari sebagian besar umat manusia disamping sumber penghidupan bagi mereka yang mencari nafkah melalui kegiatan usaha pertanian, perkebunan dan sebagainya. akademisi dan praktisi di bidang hukum. Tanah merupakan aset bagi bangsa Indonesia yaitu sebagai modal dasar pembangunan menuju masyarakat yang adil dan makmur, oleh karena itu pemanfaatannya harus didasarkan pada prinsip-prinsip yang telah tumbuh dan berkembang dalam masyarakat Indonesia. Hal ini harus dihindari dengan adanya upaya yang menjadikan tanah sebagai barang dagangan, objek spekulasi yang bertentangan dengan prinsip-prinsip yang terkandung dalam Pasal 33 ayat (3) UndangUndang Dasar 1945 (selanjutnya disebut UUD 1945). ${ }^{2}$ Berkaitan dengan pentingnya tanah bagi kelangsungan hidup bangsa masyarakat, ${ }^{3}$ maka Pemerintah menerbitkan Undang-Undang Nomor 5 Tahun 1960 tentang Pokok-Pokok Agraria atau yang biasa disebut dengan Undang-Undang Pokok Agraria (UUPA).

Landasan konstitusional mengenai kebijakan dalam hal pembangunan di bidang pertanahan pada intinya bersumber pada Pasal 33 ayat (3) UUD 1945 yang berbunyi: "Bumi dan air serta kekayaan alam yang terkandung di dalamnya dikuasai oleh Negara dan dipergunakan untuk sebesar-besar kemakmuran rakyat". Berdasarkan pada Pasal 33 ayat (3) UUD 1945, dan dengan disahkannya UUPA pada tanggal 24 September 1960, maka telah diletakkan landasan bagi penyelenggaraan administrasi pertanahan guna mewujudkan tujuan nasional. Secara hakiki makna dan posisi strategis mengenai tanah dalam kehidupan masyarakat Indonesia, tidak hanya mengandung aspek fisik saja, akan tetapi juga mengandung aspek sosial, ekonomi, budaya, politik, pertahanan keamanan dan aspek hukum. Tanah bagi masyarakat

\footnotetext{
${ }^{2}$ Arie Sukanti Hutagalung. (2008). Kewenangan Pemerintah di Bidang Pertanahan. Jakarta: Rajawali, h. 83.

${ }^{3}$ Boedi Harsono. (2003). Menuju Penyempurnaan Hukum Tanah Nasional. Jakarta: Universitas Trisakti, h. 3.
}

sendiri memiliki makna multidimensi, yaitu dari sisi ekonomi, tanah merupakan sarana produksi yang dapat mendatangkan kesejahteraan. Sedangkan secara politis tanah dapat menentukan posisi seseorang dalam pengambilan keputusan masyarakat dan sebagai budaya yang dapat menentukan tinggi rendahnya status sosial pemiliknya. ${ }^{4}$

Hak atas tanah merupakan suatu hak yang melekat dan tidak dapat dihilangkan begitu saja. Ketentuan mengenai hak-hak atas tanah diatur dalam Pasal 4 ayat (1) UUPA, yaitu bahwa atas dasar menguasai dari negara atas tanah yang ditenttukan adanya macam-macam hak atas tanah permukaan bumi yang disebut tanah yang dapat diberikan kepada dan dipunyai oleh orang-orang baik sendiri maupun bersama-sama dengan orang lain serta badan hukum. ${ }^{5}$ Hak-hak atas tanah yang dimaksud sebagaimana dalam ketentuan Pasal 4 ayat (1) UUPA, antara lain Hak Milik, Hak Guna Bangunan, Hak Guna Usaha, Hak Pakai, Hak Sewa untuk Bangunan Hak Gadai, Hak Usaha Bagi Hasil, Hak Menumpang.

Berkaitan mengenai pemegang hak atas tanah yaitu Warga Negara Indonesia, Badan Hukum Indonesia, Warga Negara Asing dan Badan Hukum Asing yang mempunyai perwakilan di Indonesia. Penduduk yang menempati wilayah Indonesia tidak hanya Warga Negara Indonesia, akan tetapi terdapat juga Warga Negara Asing yang tinggal di Indonesia. Dalam perkembangannya orang asing yang tinggal di Indonesia semakin bertambah jumlahnya, hal tersebut disebabkan adanya kemajuan ilmu pengetahuan dan teknologi, serta keterbukaan antar negara dalam hubungan Internasional. Misalnya untuk orang asing yang bekerja di Indonesia, baik itu melalui saham yang ditanamkan dalam sebuah perusahaan di Indonesia maupun perusahaan mereka yang berada di Indonesia. Ada bidang-bidang tertentu yang terbuka dan dapat dimasuki oleh perusahaan asing untuk melakukan kegiatan bisnis. Bidang dimaksud antara lain bidang pertambangan minyak dan gas bumi, bidang angkatan laut dan angkatan udara khususnya untuk angkutan luar negeri. Selain itu juga ada di

${ }^{4}$ Husein Alting. (2010). Dinamika Hukum Dalam Pengakuan dan Perlindungan Hak Masyarakat Hukum Adat Tanah (Masa Lalu, Kini dan Masa Mendatang). Ternate: Lembaga Penerbitan Universitas Khairun, h. 6.

${ }^{5}$ Urip Santoso. (2005). Hukum Agraria dan Hak-hak Atas Tanah. Jakarta: Kencana, h. 87. 
bidang perbankan, perusahaan asing hanya dapat mendirikan kantor cabangnya di Indonesia. ${ }^{6}$

Negara dalam hal ini Pemerintah harus memiliki pengaturan mengenai kepemilikan hak atas tanah khususnya bagi orang asing yang tinggal di Indonesia dan juga bagi Badan Hukum Asing yang mempunyai perwakilan di Indonesia, agar yang diamanatkan dalam Pasal 33 ayat (3) UUD 1945 tetap dapat terlaksana dengan baik, yaitu bahwa bumi, air, dan kekayaan alam yang terkandung di dalamnnya dipergunakan untuk dapat mewujudkan kemakmuran seluruh rakyat Indonesia. ${ }^{7}$

\section{PERUMUSAN MASALAH}

Berdasarkan permasalahan, maka penulis merumuskan masalah bagaimana kepastian hukum penguasaan hak atas tanah bagi badan hukum asing di Indonesia.

\section{METODE PENELITIAN}

Penelitian ini merupakan suatu penelitian hukum normatif, yaitu suatu proses untuk menemukan suatu aturan hukum, prinsip-prinsip hukum, maupun doktrin-doktrin hukum guna menjawab isu hukum yang dihadapi.

\section{PEMBAHASAN}

\section{Karakteristik Penguasaan Hak Atas Tanah}

Menurut Pasal 1 UUPA, bahwa yang dimaksud ruang lingkup bumi adalah permukaan bumi dan tubuh bumi di bawahnya, serta yang berada di bawah air. Permukaan bumi merupakan sebagai suatu bagian dari bumi yang juga disebut tanah. Tanah yang dimaksud tersebut bukan dalam hal pengaturan di segala aspek, namun hanya mengatur salah satunya, yaitu tanah dalam pengertian yuridis yang disebut hak-hak penguasaan atas tanah.

Hak atas tanah sebagaimana yang diatur dalam ketentuan Pasal 2 ayat (2) UUPA, bahwa hak menguasai dari negara memberi wewenang: a. Mengatur dan menyelenggarakan peruntukkan, penggunaan, persediaan, dan pemelihara bumi, air dan ruang angkasa; $b$. Menentukan dan mengatur hubungan-hubungan hukum antara orang-orang

\footnotetext{
${ }^{6}$ Mira Nova Ardani. "Kepemilikan Hak Atas Tanah Bagi Orang Asing Di Indonesia”. Jurnal Law Reform. Volume 13 Nomor 2 Tahun 2017, h. 204-205.

${ }^{7}$ Ibid., h. 205.
}

dengan bumi, air dan ruang angkasa; c. Menentukan dan mengatur hubungan-hubungan hukum antara orang-orang dan perbuatan-perbuatan hukum yang mengenai bumi, air dan ruang angkasa.

Sedangkan dalam Pasal 2 ayat (3) UUPA, menyebutkan bahwa wewenang yang bersumber pada hak menguasai dari negara tersebut pada ayat (2) pasal ini digunakan untuk sebesar-besar kemakmuran rakyat, dalam arti kebangsaan, kesejahteraan, dan kemerdekaan dalam masyarakat dan negara hukum Indonesia yang merdeka, berdaulat, adil, dan makmur.

Kemudian dalam Pasal 2 ayat (4), disebutkan bahwa hak menguasai dari negara tersebut di atas pelaksanaannya dapat dikuasakan kepada daerahdaerah swatantra dan masyarakat-masyarakat hukum adat, sekedar diperlukan dan tidak bertentangan dengan kepentingan nasional. ${ }^{8}$

Pengertian penguasaan dapat dipakai dalam arti fisik, juga dalam arti yuridis. Penguasaan ada yang beraspek privat dan beraspek publik. Penguasaan dalam arti yuridis merupakan penguasaan yang dilandasi hak yang dilindungi oleh hukum dan pada umumnya memberikan kewenangan kepada pemegang hak untuk menguasai secara fisik tanah yang dihaki, misalnya pemilik tanah mempergunakan atau mengambil manfaat dari tanah yang dihaki, tidak diserahkan kepada pihak lain. ${ }^{9}$

Penguasaan tanah secara yuridis, dalam hal ini memberikan kewenangan untuk dapat menguasai tanah yang dihaki secara fisik, namun kenyataannya penguasaan fisiknya dikuasai oleh pihak lain. Contoh, seseorang yang memiliki tanah tidak menggunakan tanahnya sendiri, tetapi tanah tersebut disewakan kepada pihak lain. Secara yuridis tanah tersebut merupakan milik dari pemilik tanah namun secara fisik dilakukan oleh pihak penyewa tanah. Selain itu terdapat juga penguasaan secara yuridis yang tidak memberikan kewenangan dalam hal menguasai tanah yang bersangkutan secara fisik.

Berkaitan dalam hal penguasaan ada dua unsur yang harus dipenuhi, yaitu: Pertama, adanya kenyataan bahwa subjek menguasai atau menggunakan objek dimaksud, dan Kedua, adanya sikap batin bahwa

\footnotetext{
${ }^{8}$ Vallida Anita Pieter. "Hak Penguasaan Hak Atas Tanah”. https://fhukum.unpatti.ac.id/hak-penguasaan-atas-tanah/. diunduh pada hari tanggal 10 Agustus 2020, pukul 20.57 WIB.

${ }^{9}$ Urip Santoso, op.cit., h. 73.
} 
subjek dimaksud memang mempunyai keinginan untuk menguasai atau menggunakan objeknya. Konsekuensinya pemegang kedudukan berkuasa mempunyai suatu hak untuk mempertahankan, menikmati, memanfaatkan, dan mendayagunakan benda yang ada dalam penguasaannya dengan tidak meninggalkan kewajibannya. ${ }^{10}$

Peraturan Pemerintah Nomor 16 Tahun 2014 tentang Penatagunaan Tanah, Pasal 1 angka 2 mendefinisikan bahwa penguasaan tanah adalah hubungan hukum antara perorangan, kelompok masyarakat atau badan hukum dengan tanah sebagaimana dimaksud dalam UUPA.

Pengaturan mengenai hak-hak penguasaan atas tanah dalam hukum tanah dibagi menjadi dua, yaitu: ${ }^{11}$

a. Hak Penguasaan atas tanah sebagai lembaga hukum

Hak penguasaan atas tanah ini belum dihubungkan dengan tanah dan orang atau badan hukum tertentu sebagai pemegang haknya.

Ketentuan-ketentuan dalam penguasaan atas tanah, sebagai berikut:

1. Memberi nama pada hak penguasaan yang bersangkutan;

2. Menetapkan isinya, yaitu mengatur apa saja yang boleh, wajib, dan dilarang untuk dapat diperbuat oleh pemegang haknya serta berkaitan mengenai jangka waktunya;

3. Mengatur terhadap hal-hal yang mengenai subyeknya, serta syarat-syarat bagi penguasaannya;

4. Mengatur yang berkaitan dengan hal-hal mengenai tanahnya.

b. Hak penguasaan atas tanah sebagai hubungan hukum yang konkret.

Hak penguasaan atas tanah yang dimaksud sudah dihubungkan dengan suatu tanah tertentu yang menjadikan tanah tersebut sebagai obyeknya dan kemudian orang atau badan hukum tertentu sebagai subyek atau pemegang haknya. Ketentuan-ketentuan yang berkaitan mengenai hak penguasaan atas tanah adalah sebagai berikut:

1. Mengatur hal-hal mengenai penciptaannya yang menjadi suatu hubungan hukum yang

${ }^{10}$ I Made Suwitra. (2014). Penguasaan Hak Atas Tanah dan Masalahnya. IUS Kajian Hukum dan Keadilan, h. 448.

${ }^{11}$ Ibid., h. 74. konkret, dengan nama atau sebutan hak penguasaan atas tanah tertentu;

2. Mengatur hal-hal mengenai pembebanannya dengan hak lain;

3. Mengatur hal-hal mengenai pemindahannya kepada pihak lain;

4. Mengatur hal-hal mengenai hapusnya;

5. Mengatur hal-hal mengenai pembuktiannya. ${ }^{12}$

Berkaitan dengan hubungan hukum yang mengatur antara pemegang hak dengan hak atas tanahnya, ada 8 (delapan) macam asas dalam hukum tanah, ${ }^{13}$ yaitu:

a. Asas religiositas yang memperhatikan unsurunsur yang bersandar pada hukum agama;

b. Asas kebangsaan, yang mendahulukan kepentingan nasional, dengan memberikan kesempatan kepada pihak asing untuk menguasai dan menggunakan tanah untuk keperluan usahanya, yang bermanfaat bagi kemajuan dan kemakmuran bangsa dan negara;

c. Asas demokrasi, dengan tidak mengadakan perbedaan antara gender, suku, agama dan wilayah;

d. Asas pemerataan, pembatasan dan keadilan dalam penguasaan dan pemanfaatan tanah yang tersedia;

e. Asas kebersamaan dan kemitraan dalam hal penguasaan dan penggunaan tanah dengan memperdayakan golongan ekonomi lemah, terutama petani;

f. Asas kepastian hukum dan keterbukaan dalam hal penguasaan dan penggunaan tanah serta perlindungan hukum bagi golongan ekonomi lemah, terutama golongan petani;

g. Asas penggunaan dan pemanfaatan tanah sebagai sumber daaya alam yang strategis secara berencana, optimal, efisiensi, dan berkelanjutan, daalam rangka meningkatkan kemakmuran dan kesejahteraan bersama, dengan cara menjaga kelestarian kemampuan dan lingkungannya;

h. Asas kemanusiaan yang adil dan beradab dalam penyelesaian masalah-masalah yang berkaitan

12 Markus Metusalach Ronsumbre. (2013). "Penyelesian Sengketa Penguasaan Tanah Hak Ulayat Keret Rumbiak Sebagai Kepastian Hukum Dalam Pengadaan Tanah Untuk Pembangunan Kantor Bupati di Kabupaten Biak Numfor Provinsi Papua”. Tesis. Yogyakarta: Universitas Atma Jaya Yogyakarta.

13 RachmatTrijono dan Tim. (2015). Hak Menguasai Negara di Bidang Pertanahan. Jakarta: BPHN, h. 32. 
dengan pertanahan sesuai dengan sila kedua

Pancasila.

Menurut Urip Santoso, hierarki hak-hak penguasaan atas tanah dalam Hukum Tanah Nasional, adalah: a. Hak Bangsa Indonesia atas Tanah; b. Hak menguasai dari Negara Atas Tanah; c. Hak ulayat masyarakat hukum adat; serta d. Hak perseorangan atas tanah meliputi: 1. Hak-hak atas tanah; 2. Wakaf tanah hak milik; 3. Hak Tanggungan; 4. Hak Milik atas satuan rumah susun. ${ }^{14}$

\section{Kepastian Hukum Penguasaan Hak Atas Tanah Bagi Badan Hukum Asing di Indonesia}

Konstitusi Negara Indonesia, UUD 1945 amandemen kedua Pasal 28D ayat (1) menegaskan bahwa: Setiap orang berhak atas pengakuan, jaminan, perlindungan dan kepastian hukum yang adil serta perlakuan yang sama dihadapan hukum.

Menurut Sudikno Mertoksumo, kepastian hukum adalah masyarakat mengharapkan adanya kepastian hukum, karena dengan adanya kepastian hukum tersebut masyarakat menjadi lebih tertib. ${ }^{15}$ Pengertian kepastian hukum itu sendiri berkaitan erat dengan kiprah manusia di bidang hukum yang didalamnya termasuk oleh seni hukum juga adalah mengatur manusia dan masyarakat dengan membentuk suatu undang-undang. Masyarakat dalam ini menginginkan agar tatanan masyarakat tersebut tertib sehingga kepentingan manusia dapat terlindungi. Masyarakat juga membutuhkan tatanan yang teratur serta membutuhkan stabilitas, karena stabilitas menjamin ketertiban dalam masyarakat dan menjamin kepastian hukum.

Dalam tatanan hukum pertanahan nasional, hubungan hukum antara badan hukum asing, serta perbuatan hukumnya terkait dengan tanah yang telah diatur dalam UUPA, pada Pasal 42 D yaitu bahwa badan hukum asing yang mempunyai perwakilan di Indonesia boleh menjadi pemegang hak atas tanah yaitu dengan hak pakai. Pelanggaran terhadap ketentuan pokok tersebut disertai dengan akibat hukumnya yang diatur dalam Pasal 26 ayat (2) UUPA.

Berkaitan mengenai penguasaan hak atas tanah oleh badan hukum asing di Indonesia, perlu dipahami

\footnotetext{
${ }^{14}$ Urip Santoso. op.cit., h. 11.

${ }^{15}$ Sudikno Mertokusumo. (2011). Teori Hukum. Yogyakarta: Cahaya Atma, h. 25.
}

terlebih dahulu mengenai kedudukan badan hukum asing dalam peraturan perundang-undangan di Indonesia.

1. UUPA Nomor 5 Tahun 1960 tentang Peraturan Dasar Pokok-Pokok Agraria: a. Pasal 42 huruf D, yang menyebutkan bahwa badan hukum asing yang mempunyai perwakilan di Indonesia boleh menjadi pemegang hak atas tanah, yaitu Hak Pakai; b. Pasal 45 huruf D, dipertegas yang dapat menjadi hak sewa adalah badan hukum asing yang memiliki perwakilan di Indonesia; c. Penjelasan Pasal 41 dan Pasal 42.

2. Pasal 1 angka 8 Undang-Undang Nomor 25 Tahun 2007 tentang Penanaman Modal, menyebutkan bahwa modal asing adalah modal yang dimiliki oleh negara asing, perseorangan warga negara asing, badan hukum asing, dan/ atau badan hukum Indonesia yang sebagian atau seluruh modalnya dimiliki oleh pihak asing.

3. Penjelasan Pasal 8 ayat (2) huruf a UndangUndang Nomor 40 Tahun 2007 tentang Perseroan Terbatas, menyebutkan bahwa dalam mendirikan perseroan diperlukan kejelasan mengenai kewarganegaraan pendiri. Pada dasarnya badan hukum Indonesia yang berbentuk Perseroan didirikan oleh warga negara Indonesia atau badan hukum Indonesia. Namun, kepada warga negara asing atau badan hukum asing diberikan kesempatan untuk badan hukum Indonesia yang berbentuk perseroan sepanjang undang-undang yang mengatur mengenai perseroan tersebut memungkinkan atau pendirian perseroan tersebut diatur oleh undang-undang tersendiri.

4. Pasal 39 Peraturan Pemerintah No. 40 Tahun 1996 tentang Hak Guna Usaha, Hak Guna Bangunan dan Hak Pakai Atas Tanah, mengatur yang dapat menjadi subyek Hak Pakai atas tanah, adalah warga negara Indonesia, badan hukum yang didirikan menurut hukum Indonesia dan berkedudukan di Indonesia, departemen lembaga pemerintahan non departemen dan Pemerintah daerah, Badan-badan keagamaan dan sosial, orang asing yang berkedudukan di Indonesia.

Dapat disimpulkan bahwa yang dimaksud dengan badan hukum asing adalah salah satu subyek hukum yang sah, sehingga badan hukum asing diperkenankan untuk mendirikan perseroan di Indonesia. Selain itu, juga telah dinyatakan secara 
eksplisit bahwa badan hukum asing dapat memiliki modal asing untuk berinvestasi di Indonesia sesuai dengan Undang-Undang Nomor 25 Tahun 2007 tentang Penanaman Modal dan boleh menjadi pendiri perseroan sesuai dengan Undang-Undang No. 40 Tahun 2007 tentang Perseroan Terbatas, oleh karena itu dalam hal kedudukan badan hukum asing masuk dalam pembagian badan hukum privat dan perdata. ${ }^{16}$

Saat ini di negara Indonesia, sedang terkena imbas positif dalam era globalisasi, karena para investor asing yang ingin menanamkan investasinya di Indonesia jumlahnya semakin meningkat. Akan tetapi tidak semua orang asing ataupun badan hukum asing yang mempunyai uang dapat memiliki hak atas tanah di Indonesia. Ada ketentuan-ketentuan khusus yang membatasi kepemilikan tanah dan bangunan bagi orang asing dan badan hukum asing dalam UUPA dan berbagai peraturan pelaksana lainnya yang berkaitan dengan hal tersebut. ${ }^{17}$

Menurut Adrian Sutedi bahwa berkedudukan di Indonesia adalah orang asing yang sedang melaksanakan kegiatan ekonomi di Indonesia dan pada waktu melakukan kegiatannya tersebut di Indonesia yang dilakukan secara berkala atau sewaktu-waktu, ia membutuhkan untuk mempunyai rumah tinggal atau hunian di Indonesia. ${ }^{18}$

Menurut UUPA, baik Hak Milik, Hak Guna Usaha, dan Hak Guna Bangunan tidak dapat diberikan kepada orang asing atau badan hukum asing. Bagi warga negara asing yang berkedudukan di Indonesia dapat diberikan Hak Pakai. Hal itu sesuai dengan jenisnya bahwa badan hukum dibedakan pula antara badan hukum publik dan badan hukum privat/ keperdataan. Badan hukum yang bersifat publik (perwakilan negara asing, perwakilan badan-badan internasional) dan yang bersifat keperdataan. ${ }^{19}$

Berdasarkan PP Nomor 32 Tahun 1994 jo. PP Nomor 31 Tahun 2013 yang diperkuat dengan PP

\footnotetext{
${ }^{16}$ Iwan Permadi. "Kedudukan Badan Hukum Asing Dalam Kepemilikan Hak Atas Tanah di Indonesia”. Wacana. Vol. 15 No. 4 Tahun 2012.

17 Listyowati Sumanto. "Pembatasan Pemilikan Hak Atas Tanah Oleh Orang Asing dan Badan Hukum Asing (Studi Perbandingan Indonesia-Turki)". Jurnal Hukum Prioris. Vol. 3 No. 3 Tahun 2013.

18 Adrian Sutedi. (2009). Tinjauan Hukum Pertanahan. Jakarta: Pradnya Paramita, h. 268.

19 Rokilah dan Mia Mukaromah. "Pemilikan Hak Atas Tanah Bagi Warga Negara Asing”. AJUDIKASI: Jurnal Ilmu Hukum. Vol. 2 No. 2 Tahun 2018, h. 148.
}

Nomor 40 Tahun 1996 dan PP Nomor 41 Tahun 1996, maka konsep orang asing (perseorangan) yang dapat menjadi subjek hak atas tanah di Indonesia telah mengalami perluasan. Semula, menurut semangat UUPA hanya orang asing sebagai penduduk Indonesia yang bisa menjadi subjek hak atas tanah di Indonesia. Kemudian diperluas bahwa yang menjadi subjek hak atas tanah di Indonesia, baik orang asing sebagai penduduk maupun orang asing bukan sebagai penduduk Indonesia (atau sekedar memiliki izin tinggal di Indonesia). ${ }^{20}$

Seiring dengan berjalannya waktu dan pesatnya era globalisas, semakin nampak bahwa usaha Pemerintah dalam hal mengatur mengenai kepemilikan hak atas tanah bagi warga negara asing di Indonesia belum menampakkan hasil yang maksimal dan juga belum mengatur semua aspek secara menyeluruh terhadap berbagai kebutuhan yang diinginkan oleh orang asing. Salah satu aspek penguasaan yang belum diatur dalam Peraturan Pemerintah Nomor 41 Tahun 1996 yaitu tentang pengaturan penguasaan tanah bagi badan hukum asing yang mempunyai perwakilan di Indonesia dan pengaturan penguasaan tanah yang diperuntukkan bukan untuk tempat hunian atau tempat tinggal. ${ }^{21}$

Warga negara asing dan badan hukum asing tidak terbuka kemungkinan untuk bisa mendapatkan hak atas tanah dalam sistem hukum pertanahan di Indonesia, kecuali menjadi pemegang Hak Pakai. Namun dalam hal ini warga negara asing yang menjadi investor asing dapat memiliki sebidang tanah di Indonesia dengan melalui perusahaan nasional dalam rangka Penanaman Modal Asing (PMA) yang didasarkan pada sistem Hukum Indonesia. Sedangkan apabila dikaitkan dengan tempat tinggal maka berdasarkan Keputusan Presiden Nomor 34 Tahun 1992, menyebutkan bahwa untuk tempat tinggal, maka dapat menyewa rumah milik Warga Negara Indonesia ataupun jika ingin membangun rumah sendiri maka dapat menggunakan tanah dengan status Hak Sewa atau Hak Pakai. Begitu pula bagi badan-badan hukum, baik badan hukum dengan modal asing sepenuhnya atau badan hukum yang berupa usaha patungan dengan modal Indonesia,

${ }^{20}$ FX.Sumarja. "Orang Asing Sebagai Subjek Hak Atas Tanah di Indonesia." Jurnal Masalah-Masalah Hukum. Jilid 44 Nomor 3 Juli 2015, h. 313.

${ }^{21}$ Iwan Permadi. op.cit., h. 44. 
yang berbentuk badan hukum Indonesia memiliki kemungkinan untuk dapat menggunakan hak atas tanah untuk kegiatan usahanya yaitu dengan Hak Guna Bangunan dan Hak Pakai, sedangkan bagi badan hukum dengan jenis usaha patungan dapat menggunakan Hak Guna Usaha.

Hak Pakai atas tanah sebagai salah satu jenis hak atas tanah yang dapat diatur di dalam UUPA memiliki ciri-ciri yang dapat membedakan Hak Pakai dengan hak atas tanah lainnya, yaitu dapat dimiliki oleh warga negara asing dan badan hukum asing yang mempunyai perwakilan di Indonesia. Hal ini dapat menunjukkan bahwa Hak Pakai berfungsi sebagai penunjang pelaksanaan dalam pembangungan negara. ${ }^{22}$

A.P. Parlindungan berpendapat, bahwa meskipun subyek Hak Pakai ada prinsip nasionalitas didalamnya, namun tetap ada perkecualian yaitu bahwa badan hukum asing yang mempunyai perwakilan di Indonesia dan yang telah memiliki ijin kerja di Indonesia dan menjadi subyek pemegang Hak Pakai. ${ }^{23}$

Satu sisi yang berkaitan mengenai badan hukum asing dalam hal pelaksanaan investasi di Indonesia, secara eksplisit dalam Pasal 21 Undang-Undang Penanaman Modal (yang selanjutnya disingkat UUPM, yaitu bahwa Pemerintah memberikan kemudahan dalam hal pelayanan dan/atau perizinan bagi Penanaman Modal Asing sebagai badan hukum yang didirikan berdasarkan hukum Indonesia dan berkedudukan di Indonesia, untuk dapat memperoleh hak atas tanah.

Sedangkan persyaratan tentang kemudahan untuk dapat diberikan dan diperpanjang di muka sekaligus untuk kegiatan penanaman modal diatur dalam ketentuan Pasal 22 ayat (2) UUPM, antara lain: a. Penanaman modal yang dilakukan dalam jangka panjang dan terkait dengan perubahan struktur perekonomian Indonesia; b. Penanaman modal dengan tingkat resiko penanaman modal yang memerlukan pengembalian modal dalam jangka panjang sesuai dengan jenis kegiatan penanaman modal yang dilakukan; c. Penanaman modal yang tidak memerlukan area yang luas; d. Penanaman modal dengan menggunakan hak atas tanah negara; e. Penanaman modal yang tidak mengganggu

$$
\begin{aligned}
& 22 \text { ibid. } \\
& 23 \text { ibid. }
\end{aligned}
$$

rasa keadilan masyarakat dan tidak merugikan kepentingan umum.

Pemberian fasilitas hak atas tanah tersebut bermaksud untuk dapat memberikan kemudahan terhadap para investor untuk menanamkan investasinya di Indonesia. Akan tetapi berkaittan dengan jangka waktu penggunaan hak atas tanah yang diberikan bagi investor terhitung sangat lama. Hal itu jelas sangat bertentangan dengan jangka waktu yang telah ditetapkan dalam UUPA dan Peraturan Pemerintah Nomor 40 Tahun 1996 tentang Hak Guna Usaha, Hak Guna Bangunan dan Hak Pakai Atas Tanah. Selain itu, pengaturan berkaitan dengan jangka waktu bagi penggunaan hak atas tanah yang diatur dalam ketentuan UUPM juga bertentangan dengan Pasal 33 ayat (2) UUD 1945 yang memberikan dasar bagi jalannya suatu kewenangan sebagaimana yang telah dituangkan dalam Hukum Tanah Nasional yang diatur dalam UUPA. ${ }^{24}$

Hak-hak atas tanah yang diberikan kepada investor diantaranya seperti Hak Guna Usaha (HGU), Hak Guna Bangunan (HGB), dan Hak Pakai. Dalam hal pemberian hak atas tanah yang merupakan kewenangan negara muncul tuntutan adanya penyesuaian substansinya. ${ }^{25}$

Hubungan hukum yang mengatur antara orangorang dan badan hukum, terwujud dalam bentuk prinsip Nasionalitas, yaitu bahwa hanya warga negara Indonesia yang dapat memiliki hubungan sepenuhnya dengan tanah. Sedangkan pengaturan mengenai penguasaan tanah bagi badan hukum asing yang mempunyai perwakilan di Indonesia secara terperinci sangat penting dengan tujuan untuk mencegah terjadinya perbuatan-perbuatan yang dapat melanggar hukum dalam rangka mendapatkan hak penguasaan atas tanah bagi badan hukum asing.

Mengenai aspek keadilan di dalam peraturan perundang-undangan yang berkaitan kedudukan warga negara asing dan badan hukum asing dalam hukum pertanahan di Indonesia, dapat dilihat dari dua sisi. Satu sisi warga negara asing dan badan hukum asing diberikan kesempatan untuk dapat memiliki hak atas tanah beserta dengan bangunannya, akan

${ }^{24}$ Dyah Ayu Grashinta, http://lib.ui.ac.id, Diakses pada tanggal 11 Agustus 2020, Pukul 19.00 WIB.

${ }^{25}$ Natanael Dwi Reki. "Pembatasan Pemilikan Penguasaan Hak Atas Tanah Dalam Perspektif Performa Agraria”. Jurnal Hukum Magnum Opus. Volume I Nomor 1 Agustus 2018, h. 2. 
tetapi di sisi yang lainnya dimaksudkan agar tidak mengurangi terhadap perlindungan hukum yang diberikan pemerintah kepada warga negara Indonesia. Terutama apabila terdapat warga negara Indonesia yang membutuhkan bantuan secara ekonomis, maka akan diberikan persyaratan bagi warga negara asing dan badan hukum asing untuk dapat memiliki hak atas tanah beserta dengan bangunannya dengan beberapa pembatasan yang telah dijelaskan. ${ }^{26}$

\section{PENUTUP}

\section{Kesimpulan}

Warga negara asing dan badan hukum asing tidak terbuka kemungkinan untuk bisa mendapatkan hak atas tanah dalam sistem hukum pertanahan di Indonesia, kecuali menjadi pemegang Hak Pakai. Namun dalam hal ini warga negara asing yang menjadi investor asing dapat memiliki sebidang tanah di Indonesia dengan melalui perusahaan nasional dalam rangka Penanaman Modal Asing (PMA) yang didasarkan pada sistem Hukum Indonesia. Hak Pakai atas tanah sebagai salah satu jenis hak atas tanah yang dapat diatur di dalam UUPA memiliki ciri-ciri yang dapat membedakan Hak Pakai dengan hak atas tanah lainnya, yaitu dapat dimiliki oleh warga negara asing dan badan hukum asing yang mempunyai perwakilan di Indonesia. Hal ini dapat menunjukkan bahwa Hak Pakai berfungsi sebagai penunjang pelaksanaan dalam pembangunan negara. Namun pemerintah memberikan kemudahan kepada badan hukum asing dalam hal pelaksanaan investasi di Indonesia sebagaimana yang diatur dalam UUPM. Hal tersebut jelas bertentangan dengan prinsip Nasionalisme dalam UUPA.

\section{Rekomendasi}

Badan hukum asing harus diatur secara eksplisit dalam hal penguasaan hak atas tanah, khususnya yang berkaitan dengan pelaksanaan investasi yang tidak bertentangan dengan UUD 1945 dan UUPA. Sehingga badan hukum asing dapat mempunyai kepastian hukum dalam hal penguasaan hak atas tanah di Indonesia.

\footnotetext{
${ }^{26}$ Michael Wisnoe. (2012). Tesis. "Kepemilikan Hak Atas Tanah Bagi Warga Negara Asing dan Kewarganegaraan Ganda". Depok: Fakultas Hukum Universitas Indonesia, h. 50.
}

\section{DAFTAR PUSTAKA}

\section{Peraturan Perundangan-undangan:}

Undang-Undang Dasar Negara Republik Indonesia Tahun 1945.

Undang-Undang Nomor 5 Tahun 1960 tentang Pokok-Pokok Agraria.

Undang-Undang Nomor 25 Tahun 2007 tentang Penanaman Modal.

Undang-Undang Nomor 40 Tahun 2007 tentang Perseroan Terbatas.

Peraturan Pemerintah Nomor 40 Tahun 1996 tentang Hak Guna Usaha, Hak Guna Bangunan, dan Hak Pakai Atas Tanah.

Peraturan Pemerintah Nomor 41 tahun 1996 tentang Pemilikan Rumah Tempat Tinggal atau Hunian Oleh Orang Asing Yang Berkedudukan di Indonesia.

Peraturan Pemerintah Nomor 16 Tahun 2014 tentang Penatagunaan Tanah.

Keputusan Presiden Nomor 34 Tahun 1992 tentang Pemanfaatan Tanah Hak Guna Usaha dan Hak Guna Bangunan Untuk Usaha Patungan Dlam Rangka Penanaman Modal Asing.

Peraturan Menteri Negara Agraria/Kepala BPN Nomor 7 Tahun 1996 tentang Persyaratan Pemilikan Rumah Tempat Tinggal atau Hunian Oleh Orang Asing.

\section{Buku:}

Adrian Sutedi. (2009). Tinjauan Hukum Pertanahan. Jakarta: Pradnya Paramita.

Arie Sukanti Hutagalung. (2008). Kewenangan Pemerintah di Bidang Pertanahan. Jakarta: Rajawali.

Boedi Harsono. (2003). Menuju Penyempurnaan Hukum Tanah Nasional. Jakarta: Universitas Trisakti.

Husein Alting. (2010). Dinamika Hukum Dalam Pengakuan dan Perlindungan Hak Masyarakat Hukum Adat Tanah (Masa Lalu, Kini dan Masa Mendatang). Ternate: Lembaga Penerbitan Universitas Khairun.

I Made Suwitra. (2014). Penguasaan Hak Atas Tanah dan Masalahnya. IUS Kajian Hukum dan Keadilan.

Sudikno Mertokusumo. (2011). Teori Hukum. Yogyakarta: Cahaya Atma. 
Urip Santoso. (2005). Hukum Agraria dan Hak-hak Atas Tanah. Jakarta: Kencana.

\section{Jurnal:}

Anna Triningsih dan Zaka Firma Aditya. (2019). "Pembaharuan Penguasaan Hak Atas Tanah Dalam Perspektif Konstitusi”. Rechtsvinding. Vol. 8 No. 3. 2019. h. 330.

FX.Sumarja. "Orang Asing Sebagai Subjek Hak Atas Tanah di Indonesia." Jurnal Masalah-Masalah Hukum. Vol. 44. No. 3. 2015. h. 313.

Iwan Permadi. "Kedudukan Badan Hukum Asing Dalam Kepemilikan Hak Atas Tanah di Indonesia". Wacana. Vol. 15 No. 4. 2012.

Listyowati Sumanto. "Pembatasan Pemilikan Hak Atas Tanah Oleh Orang Asing dan Badan Hukum Asing (Studi Perbandingan Indonesia-Turki)". Jurnal Hukum Prioris. Vol. 3. No. 3. 2013.

Mira Nova Ardani. "Kepemilikan Hak Atas Tanah Bagi Orang Asing Di Indonesia". Jurnal Law Reform. Vol. 13. No. 2. 2017. h. 204-205.
Natanael Dwi Reki. "Pembatasan Pemilikan Penguasaan Hak Atas Tanah Dalam Perspektif Performa Agraria”. Jurnal Hukum Magnum Opus. Vol. I. No. 1. 2018. h. 2.

Rokilah dan Mia Mukaromah. "Pemilikan Hak Atas Tanah Bagi Warga Negara Asing". AJUDIKASI: Jurnal Ilmu Hukum. Vol. 2. No. 2. 2018. h. 148.

\section{Tesis:}

Markus Metusalach Ronsumbre. (2013). "Penyelesian Sengketa Penguasaan Tanah Hak Ulayat Keret Rumbiak Sebagai Kepastian Hukum Dalam Pengadaan Tanah Untuk Pembangunan Kantor Bupati di Kabupaten Biak Numfor Provinsi Papua”. Tesis. Yogyakarta: Universitas Atma Jaya Yogyakarta.

\section{Website:}

Dyah Ayu Grashinta, http://lib.ui.ac.id, Diakses pada tanggal 11 Agustus 2020, Pukul 19.00 WIB.

Vallida Anita Pieter. "Hak Penguasaan Hak Atas Tanah". https://fhukum.unpatti.ac.id/hakpenguasaan-atas-tanah/. diunduh pada hari tanggal 10 Agustus 2020, pukul 20.57 WIB. 